\title{
Peran Perawat dalam Diagnosa Keperawatan
}

\author{
Eka Rosliani Nasution \\ ekaroslianinasution1303@gmail.com
}

\begin{abstract}
Abstrak
Salah satu kegiatan yang penting dalam proses keperawatan adalah pengkajian keperawatan. Pengalaman menunjukkan bahwa sering sekali perawat kesulitan dalam menentukan diagnosis keperawatan spesifik yang dialami oleh pasien. Hal ini mungkin karena pengkajian keperawatan yang tidak terstruktur dengan baik. Sejauh ini belum ada standar asuhan keperawatan yang disepakati terkait perawatan pasien dengan gangguan pernapasan. Dokumentasi keperawatan yang sesuai standar bahasa keperawatan (Standarized Nursing Language), masih merupakan masalah di dalam profesi perawat, khususnya keseragaman dalam penggunaan bahasa diagnosa dan intervensi keperawatan. Dibutuhkan suatu instrumen untuk bisa menghasilkan dokumentasi diagnosis dan intervensi yang baik.Berbagai penelitian menunjukkan bahwa penulisan dokumentasi asuhan keperawatan di fasilitas kesehatan khususnya rumah sakit belum optimal. Hal ini disebabkan oleh faktor-faktor seperti perawat yang lebih suka berinteraksi langsung dengan pasien, rendahnya pemahaman tentang menulis dokumentasi dan mencatat asuhan keperawatan dirasakan membebani sehingga diperlukan pedoman praktis dan mudah diinstal dan digunakan pada smartphone sehingga perawat mudah menerapkan dan hemat waktu dalam pendokumentasian. Penelitian ini bertujuan untuk mengetahui efektivitas pedoman pendokumentasian diagnosa dan intervensi keperawatan berbasis android terhadap peningkatan mutu dokumentasi diagnosis dan intervensi keperawatan.
\end{abstract}

\section{Latar Belakang}

Asuhan keperawatan adalah suatu pendekatan untuk pemecahan masalah yang memampukan perawat untuk mengatur dan memberikan asuhan keperawatan. Standar asuhan yang tercantum dalam Standar Praktik Klinis Keperawatan terdiri dari lima fase asuhan keperawatan: 1) Pengkajian; 2) Diagnosa; 3) Perencanaan; 4) Implementasi; dan 5) Evaluasi. Salah satu manfaat dari penerapan asuhan keperawatan yang baik adalah meningkatkan mutu dan kualitas pelayanan dalam bidang keperawatan (Kozier, 2010).

Pada prakteknya kegiatan proses keperawatan di atas tidaklah selalu berurutan tetapi bisa dikerjakan pada waktu bersamaan/tumpang tindih (overlapping). Salah satu kegiatan yang penting dalam proses keperawatan adalah pengkajian keperawatan. Pengkajian keperawatan ini sangat penting karena dari pengkajian keperawatan maka perawat akan mampu menentukan apa masalah keperawatan/diganosa keperawatan dan masalah kolaboratif/diagnosis potensial komplikasi yang dialami oleh pasien dan membuat perencanaan dalam merawat pasien.

Pengalaman menunjukkan bahwa sering sekali perawat kesulitan dalam menentukan diagnosis keperawatan spesifik yang dialami oleh pasien.Hal ini mungkin karena pengkajian keperawatan yang tidak terstruktur dengan baik.Pengalaman menunjukkan bahwa pengkajian yang dilakukan oleh perawat tidak mempunyai urutan yang runut dan terkait dengan diagnosis keperawatan.Sering terjadi perawat mempunyai data tertentu tetapi kebingungan untuk menentukan data tersebut mendukung diagnosis keperawatan yang mana. Atau sebaliknya perawat mempunyai prediksi pasien mempunyai diagnosis tertentu tetapi tidak tahu data apa yang perlu dikaji untuk mendukung diagnosis tersebut muncul (Nurjannah, 2010).

Panduan penulisan diagnosis keperawatan NOC, NIC (2011), menyatakan bahwa diagnosis 
keperawatan yang timbul pada pasien penyakit pernafasan ada beberapa diagnosis, diantaranya bersihan jalan nafas tidak efektif, pola nafas tidak efektif, gangguan pertukaran gas, kurang pengetahuan, resiko aspirasi, dan ketidakseimbangan nutrisi kurang dari kebutuhan tubuh (Herman, 2014 ).

Sejauh ini belum ada standar asuhan keperawatan yang disepakati terkait perawatan pasien dengan gangguan pernapasan. Sedangkan proses mengkaji dan mendiagnosis merupakan kegiatan yang sangat penting karena menentukan keberhasilan keperawatan. Dalam merumuskan diagnosis keperawatan menurut Wilkinson (2007) terdapat beberapa kegiatan yang dilakukan dalam mendiagnosis keperawatan adalah interpretasi dari data yang ada, kemudian melakukan verifikasi dengan pasien, menentukan label diagnosis keperawatan dan menuliskan diagnosis keperawatan.

Menurut beberapa perawat, pendokumentasian yang selama ini mereka lakukan cukup memakan waktu karena harus menuliskannya secara manual, sehingga terkadang kegiatan pendokumentasian jarang dilakukan. Perawat lebih banyak menghabiskan waktunya untuk melakukan tindakan pada pasien tanpa mempertimbangkan aspek dokumentasi. Permasalahan lain yang muncul adalah belum adanya standar bahasa keperawatan yang digunakan dalam proses dokumentasi sehingga terjadi perbedaan antara satu perawat dengan perawat di ruangan lain.

Perawat dalam mengatasi masalah di atas memerlukan pedoman dokumentasi atau sistem informasi yang dapat mengakomodasi data yang dibutuhkan secara sistematis dan efisien, salah satunya adalah pedoman pendokumentasian diagnosa dan intervensi berbasis android yang berisi data diagnosa dan intervensi keperawatan yang merujuk pada sepuluh kasus besar penyakit di Rumah Sakit SM, dan berdasar NANDA (North American Nursing Diagnosis Association), Depkes RI, SDKI (Standar Diagnosa Keperawatan Indonesia), Q-DIO (Quality of Nursing Diagnosis Intervention and Outcomes) dan NIC (Nursing Intervention Classification), serta NOC (Nursing Outcome Classification). Penerapan pedoman dokumentasi berbasis android merupakan upaya untuk meningkatkan mutu dan kelengkapan dokumentasi asuhan keperawatan, terutama dokumentasi diagnosa dan intervensi keperawatan. Aplikasi ini diharapkan dapat digunakan sebagai panduan oleh perawat dalam mendokumentasikan asuhan keperawatan sehingga dapat menghemat waktu, lebih praktis dan mudah diterapkan dan dapat membantu dokumentasi kearah standar. Aplikasi ini meningkatkan akurasi dan efisiensi penulisan dokumentasi keperawatan, memfasilitasi komunikasi antara perawat ketika merawat pasien, dan mencegah kesalahan pengobatan (Efendi, 2017).

Layanan asuhan keperawatan yang baik harus terstruktur dan berkelanjutan, ini akan memudahkan perawat dalam menangani masalah pasien. Pemberian asuhan keperawatan terkadang tidak akurat karena kelalaian perawat sehingga dibutuhkan sebuah pedoman yang dapat memuat data-data asuhan keperawatan yang mudah diakses dan digunakan. Aplikasi ini berguna untuk membantu perawat melakukan tugas secara efektif dan efisien karena aplikasi ini dilengkapi dengan data asuhan keperawatan berbasis NANDA, dan, NIC-NOC (Segara, 2013).

Salah satu metode dalam menilai kinerja perawat yaitu dengan melihat standar asuhan keperawatan. Standar asuhan keperawatan adalah suatu pernyataan yang menguraikan kualitas yang diinginkan terkait dengan pelayanan keperawatan terhadap pasien yang prosesnya terdiri dari pengkajian, diagnosa, intervensi, implementasi dan evaluasi yang berguna terwujudnya kinerja perawat yang profesional (Herwyndianata, 2013).

Kinerja perawat dalam pemberian asuhan keperawatan dapat dipengaruhi salah satunya oleh faktor tingkat organisasi rumah sakit seperti lingkungan kerja perawat. Menurut Robbins (2015) berpendapat lingkungan kerja dalam suatu organisasi mempunyai peranan penting untuk kelancaran proses produksi karena lingkungan kerja yang baik tidak hanya dapat memuaskan karyawan dalam melakasanakan tugas, tetapi juga berpengaruh dalam meningkatkan kinerja karyawan. Menurut Susialisasi (2011) Lingkungan kerja merupakan salah satu penyebab dari keberhasilan dalam melaksanakan suatu pekerjaan tetapi juga dapat menyebabkan suatu kegagalan dalam pelaksanakan 
suatu pekerjaan.

Sedangkan menurut Yunanda (2012) Lingkungan kerja merupakan salah satu faktor yang mengaruh langsung pada aktivitas kerja setiap individu. Lingkungan kerja yang kondusif menciptakan kenyamanan dan kehidupan kerja yang lebih baik, lingkungan kerja memuaskan menimbulkan keterikatan perawat pada rumah sakit yang merupakan faktor yang menentukan kualitas perawatan pasien. Lingkungan kerja yang berkualitas tinggi bermanfaat bagi perawat dan dapat meningkatkan kualitas perawatan klien. Komponen dari lingkungan kerja perawat antara lain meliputi komponen kepemimpinan dan budaya; kendali terhadap praktek; kendali terhadap beban kerja; dan sumber-sumber yang adekuat bagi terlaksananya pelayanan keperawatan yang berkualitas (PPNI, 2005).

Keperawatan merupakan profesi unik yang memiliki fokus utama caring, yaitu bagaimana memberikan dan mengelola asuhan yang dibutuhkan pasien. Hal ini menjadikan perawat memiliki peran baik pemberi asuhan sebagai kemampuan klinis dan juga koordinator sebagai komponen manajerial. Peran perawat sebagai pemberi asuhan merupakan komponen penting yang esensial dalam sistem pemberian pelayanan kesehatan. Kemampuan dan keterampilan perawat yang kuat dalam kepemimpinan dan administratif sangat penting bagi pasien dan keselamatannya serta sistem layanan dan aksesnya. Mutu asuhan yang unggul dapat memenuhi kebutuhan masyarakat terhadap kesehatan. Tuntutan tersebut membuat perawat perlu dipersiapkan dengan baik untuk membuat dan memelopori strategi perubahan dan mengelola secara efektif koordinasi dan integrasi dari tim interdisipliner, kebutuhan masyarakat, dan sistem asuhan yang berkelanjutan (Rabelo et al., 2016). Itulah sebabnya, integrasi asuhan keperawatan dan manajemen keperawatan menjadi salah satu inti kompetensi yang dibutuhkan perawat untuk menjalankan peran dan fungsinya dalam lingkungan layanan asuhan kesehatan.

Asuhan keperawatan merupakan proses sistematis, terstruktur, dan integratif dalam badan keilmuan keperawatan. Asuhan ini diberikan melalui metode yang disebut proses keperawatan. Proses keperawatan yang didasari teori Orlando Deliberative Nursing Process ini menyatakan bahwa tindakan atau perilaku yang ditunjukkan perawat merupakan hasil pertimbangan berdasarkan kebutuhan pasien. Hal tersebut berarti bahwa perawat profesional melakukan eksplorasi kebutuhan dan masalah atau gangguan kebutuhan yang terjadi pada pasien dengan menggunakan persepsi, proses berpikir kritis, penalaran klinis, dan atau perasaan perawat yang berhubungan dengan kebutuhan dasar pasien. Proses keperawatan membantu perawat mendapatkan luaran, mengukur kualitas pelaksanaan asuhan keperawatan dan memudahkan perawat untuk melakukan praktik klinis keperawatan khususnya bagi perawat pemula (Xiao et al., 2017). Proses keperawatan terdiri dari lima tahapan, yaitu pengkajian, diagnosis, perencanaan, implementasi, dan evaluasi.

Proses keperawatan merupakan gambaran dari hubungan antara pasien dan perawat, identitas dan peran profesionalitas perawat, dan pengembangan pengetahuan perawat. Antusiasme perawat dalam menerima tantangan baru dalam memberikan pelayanan telenursing sangat tinggi, hal tersebut dapat berdampak pada kemampuan meningkatkan komunikasi yang efektif antara perawat dan pasien (Padila et al., 2018). Hubungan antara pasien dan perawat merupakan interaksi timbal balik dimana respon pasien dan perawat saling memengaruhi dan terus berkembang sejalan dengan perubahan respon antara pasien dan perawat. Salah satu fungsi profesionalitas perawat adalah menemukan kebutuhan pasien yang tidak terpenuhi dan kemudian memberikan bantuan untuk memenuhi kebutuhan tersebut. Proses keperawatan memfasilitasi perawat untuk berkembang sebagai seorang pemikir yang logis untuk menghasilkan peningkatan respon dan perilaku pasien dalam pemenuhan kebutuhannya serta pentingnya partisipasi pasien dalam keseluruhan proses (Stonehouse, 2017).

Diagnosis keperawatan merupakan sebuah konsep kritis untuk memandu proses pengkajian dan intervensi (Rabelo et al., 2016). Diagnosis juga menjadi komunikasi dan basis ilmu keperawatan dalam interaksinya dengan disiplin ilmu lain. Diagnosis keperawatan merupakan penilaian perawat berdasarkan respon pasien secara holistik (bio-psiko-sosio-spiritual) terhadap 
penyakit atau gangguan kesehatan yang dialaminya. Diagnosis sama pentingnya serta memiliki muatan aspek legal dan etis yang sama dengan diagnosis medis. Oleh karena itu, diagnosis keperawatan merupakan kunci perawat dalam membuat rencana asuhan yang diberikan pada pasien yang dikelola. Proses identifikasi gangguan kebutuhan berdasarkan respon yang didapat dari pasien diperoleh dari proses pengkajian keperawatan dan kemudian dianalisis untuk penarikan kesimpulan atau keputusan klinis dalam bentuk diagnosis keperawatan. Diagnosis keperawatan mendeskripsikan respon manusia (pasien) terhadap adanya masalah atau gangguan potensial atau aktual, sementara diagnosis medis merupakan konsep yang mendeskripsikan proses penyakit atau injuri. North America Nursing Diagnosis Association (NANDA) yang kemudian berkembang menjadi NANDA- Internasional (NANDA-I) untuk pengembangan dan penggunaan standarisasi terminologi diagnosis keperawatan untuk meningkatkan status kesehatan secara global. Proses pengembangan terus dilakukan untuk perbaikan diagnosis berdasarkan praktik berbasis bukti untuk menentukan tujuan (outcome) dan intervensi yang akan direncanakan dan diberikan kepada pasien (Herdman \& Kamitsuru, 2018). Semakin pendeknya interval diagnosis NANDA-I pada kedua edisi terakhir menunjukkan bahwa perawat perlu lebih sering memperbaharui profesionalitasnya dalam konteks proses keperawatan mengikuti standarisasi yang ada.

Penetapan luaran atau outcome mengarahkan perawat tetap fokus terhadap masalah yang dialami pasien dan menetapkan indikator pencapaian yang kemudian akan menjadi evaluasi perkembangan respon pasien terhadap intervensi yang diberikan perawat. Setiap indikator dibuat terukur untuk memudahkan evaluasi. Oleh karena itu, pendekatan Nursing Outcome Classification (NOC) dan Nursing Intervention Classification (NIC) dapat menjadi panduan perawat dalam menyusun perencanan yang terfokus, sistematis, dan terstruktur dalam proses keperawatan khususnya penetapan tujuan, indikator pencapaian, dan perencanaan intervensi. Muryani et al., (2019) mengungkapkan bahwa seluruh pengkajian keperawatan terdokumentasi tidak sesuai dengan standar (100\%).

Dalam hal ini perawat belum menerapkan standar asuhan yang terdokumentasi sebagai aspek legal dalam pelayanan keperawatan. Namun, dari penelitian sebelumnya belum memaparkan aspek kualitas dokumentasi asuhan keperawatan secara deskriptif untuk memberikan gambaran jelas aspek mana dari proses keperawatan yang sering kali penerapannya tidak sesuai dengan standar yang ada. Selain itu, dirasa perlu mengukur gambaran aplikasi standar berdasarkan standar yang dikeluarkan oleh organisasi profesi sebagai acuan dalam penetapan standar asuhan keperawatan di Indonesia.

\section{Metode}

Metode pendokumentasian diagnosa keperawatan yang mengharapkan membuat diagnosa keperawatan dengan sistem pencatatan yang relevan. Adapun persyaratan dari diagnosa keperawatan ialah perumusan wajib jelas dan singkat dari respons klien terhadap situasi yang dihadapi, spesifik dan akurat, memberikan arahan pada askep, bisa dikerjakan oleh perawat dan mencerminkan keadaan kesehatan klien (Zulfikar, 2015).

Perencanaan merupakan tahap selanjutnya setelah pengkajian dan penentuan diagnosa keperawatan. Perencanaan juga merupakan petunjuk tertulis yang menggambarkan secara tepat mengenai rencana tindakan yang dilakukan terhadap pasien sesuai dengan tingkat kebutuhan berdasarkan diagnosa keperawatan yang muncul. Untuk itu rencana tindakan yang baik tentunya harus berdasarkan pada diagnosa keperawatan yang telah dirumuskan (Hartati, Handoyo, Anis, 2010). Tahap perencanaan merupakan suatu proses penyusunan berbagai intervensi keperawatan yang dibutuhkan untuk mencegah, menurunkan atau mengurangi masalah-masalah klien. Dalam menentukan tahap perencanaan bagi perawat diperlukan berbagai pengetahuan dan keterampilan diantaranya pengetahuan tentang kekuatan dan kelemahan klien, nilai dan kepercayaan klien, 
batasan praktek keperawatan, peran dari tenaga kesehatan lainnya, kemampuan dalam memecahkan masalah, mengambil keputusan, menulis tujuan serta memilih dan membuat strategi keperawatan yang aman dalam memenuhi tujuan, menulis instruksi keperawatan serta kemampuan dalam melaksanakan kerja sama dengan tingkat kesehatan lain.

\section{Hasil}

Keperawatan merupakan suatu proses perawatan yang dilakukan oleh perawat yang memiliki sasaran yaitu manusia yang di pandang sebagai makhluk holistik yang meliputi biopsikososio- spiritual-kultural yang harus dipahami oleh perawat sehingga dalam memberikan asuhan keperawatan perlu memperhatikan aspek-aspek tersebut (Asmadi, 2008). Perawat memiliki fungsi dan peran yang penting dalam melaksanakan asuhan keperawatan yang profesional. Salah satu peran perawat adalah memberi asuhan keperawatan bagi pasien. Akuntabilitas perawat sebagai profesi diantaranya adalah kompetensinya dalam mendokumentasikan diagnosa keperawatan sesuai standar diagnosa keperawatan Indonesia (SDKI).

Kompetensi ini dibutuhkan dalam rangka menjamin kualitas asuhan keperawatan kepada masyarakat. Rumah sakit merupakan institusi pelayanan yang memiliki organisasi yang kompleks dengan multi profesi, multi kompetensi, multi produksi sehingga memungkinkan terjadi banyak kesalahan atau error dalam memberikan pelayanan kepada masyarakat.

SDKI merupakan standar mutu proses bagi pelayanan keperawatan di rumah sakit khususnya yang akan melandasi standar asuhan keperawatan nantinya. SDKI harus memenuhi beberapa persyaratan antara lain tidak lepas dari standar diagnosa keperawatan internasional; memiliki evidence based yang kuat, merupakan hasil survei dari RS, puskesmas, kementerian kesehatan, riset dan pendidikan keperawatan di Indonesia.

\section{Pembahasan}

Diagnosis keperawatan Bersihan jalan napas tidak efektif dan Pola napas tidak efektif selalu ditegakkan oleh perawat ruangan dan peneliti. Frekuensi kemunculan yang sering pada kedua diagnosiskeperawatanini,tidakhanya dilakukan oleh perawat ruangan, namun juga berdasarkan pengkajian NANDA- ISDA. Hal ini sesuai dengan hasil penelitian (Andrade, et.al. 2012), bahwa diagnosis Pola napas tidak efektif, Bersihan jalan napas tidak efektif dan Gangguan pertukaran gas merupakan diagnosis keperawatan yang paling banyak ditegakkan oleh perawat berdasarkan

ISSN 1907 - 0357 serangkaian data pada pasien dengan gangguan pernapasan Pneumonia dan Asma. Hal ini juga sesuai pendapat Antipuesto (2009), bahwa pasien dengan gangguan respirasi akan mengalami masalah Bersihan jalan napas tidak efektif, Pola napas tidak efektif, Gangguan pertukaran gas, Kurang pengetahuan, dan Ansietas. Semua responden terpasang infus, namun tidak ada perawat yang menegakkan diagnosis keperawatan "Risiko trauma vaskular". Berdasarkan pengkajian NANDA-ISDA, data pemasangan infus akan memunculkan diagnosis keperawatan Risiko trauma vaskular.

Menurut Saputra (2013), komplikasi pemasangan infus diantaranya adalah hematoma, infiltrasi, tromboplebitis dan emboli udara. Diagnosis keperawatan Nausea, dialami oleh hampir sebagian besar responden, besar kemungkinan karena efek samping obat, namun tidak ditegakkan sebagai diagnosis keperawatan oleh perawat ruangan. Kinerja perawat pelaksana dalam pelaksanaan asuhan keperawatan merupakan upaya meningkatan mutu pelayanan keperawatan yang diberikan dalam bentuk kinerja perawat dan harus didasari kemampuan yang tinggi sehingga kinerja mendukung pelaksanaan tugas dalam pelayanan keperawatan. Kinerja merupakan suatu hasil kerja seseorang yang dilakukan sesuai dengan tugas dalam suatu organisasi (Nursalam, 2015). Sedangkan menurut Efendi (2015) kinerja perawat yang baik merupakan jembatan dalam menjawab jaminan kualitas pelayanan kesehatan yang diberikan terhadap pasien baik yang sakit maupun sehat. Kunci 
utama dalam peningkatan kualitas pelayanan kesehatan adalah perawat yang mempunyai kinerja tinggi. Perilaku kerja (performance) yang dihasilkan perawat tidak lepas dari faktor yang mempengaruhinya.

Kualitas asuhan yang berfokus pada tampilan kinerja keperawatan melalui proses keperawatan merupakan sebuah indikator yang penting dan dapat diukur dari dokumentasi keperawatan (Xiao et al., 2017). Sejarah fokus dokumentasi keperawatan sebelumnya berorientasi pada dokumentasi proses keperawatan yang komprehensif dan kemudian berkembang menjadi diagnosis keperawatan yang lengkap namun belum memerhatikan kualitas dari dokumentasi diagnosis keperawatan, intervensi, dan luaran. Hubungan yang logis, berdasarkan teori, dan koheren antara diagnosis, luaran pasien, dan intervensi keperawatan menjadi penekanan yang penting, bahkan diagnosis keperawatan menjadi tidak berfungsi tanpa adanya kaitan dengan luaran dan intervensi. Luaran keperawatan menjadi "jembatan" untuk menstandarisasi hubungan antara diagnosis dengan intervensi. Sedangkan, intervensi keperawatan dinilai untuk mengevaluasi efek intervensi terhadap diagnosis. Diagnosis keperawatan berfungsi untuk meningkatkan kualitas pengkajian yang dilakukan dan didokumentasikan oleh perawat. Diagnosis keperawatan sebagai proses terkait pada kajian deskripsi masalah pasien, penyebabnya, dan dapat memberikan informasi kepada perawat untuk mengidentifikasi pendekatan kajian apa yang sesuai untuk membuat perencanaan spesifik terkait diagnosis keperawatan pasien. Sehingga, secara tidak langsung akan membuat pengkajian perawat lebih komprehensif dan spesifik berorientasi pada masalah dan diagnosis pasien.

Situasi aktual atau nyata yang mendukung dilakukannya rawat inap pada pasien umumnya didapatkan dari keluhan utama pasien secara spesifik yang mengakibatkan pasien mencari layanan perawatan dan biasanya berhubungan dengan penyakitnya. Namun ada persepsi bahwa keluhan utama adalah keluhan yang pasien sampaikan secara subyektif pada saat interaksi pertama kali, padahal tidak semua yang dikeluhkan pasien saat pertama kali berinteraksi dengan perawat merupakan alasan pasien datang ke layanan kesehatan tetapi apa yang pasien rasakan pada saat ditanya oleh perawat. Kalimat pertanyaan "Apa keluhannya Pak/Bu?" atau "Apa yang dirasakan Pak/Bu?" sebenarnya belum spesifik bertujuan menggali alasan pasien mencari layanan kesehatan, dan ambigu dengan beda interpretasi seperti "apa yang dirasakan saat ini (saat ditanya)" alih-alih "kenapa datang ke rumah sakit". Oleh karena itu, perlu ada kajian yang lebih dalam (in-depth interview) hingga tergali etiologi dasar dari masalah kesehatan pasien, dan yang didokumentasikan adalah tanda gejala yang dirasakan pasien.

Hal inilah yang mengakibatkan prioritas keperawatan menjadi tidak relevan berdasarkan pengkajian. Tetapi, jika pengkajian lebih lanjut dilakukan, maka akan didapatkan bahwa pasien yang mengalami ketidakstabilan tekanan darah dapat mengakibatkan kondisi mual atau muntah, sehingga akan didapatkan Diagnosis Risiko Ketidakstabilan Tekanan Darah. Oleh karena itu, akan pasien kemudian dapat didiagnosis Ketidakstabilan Tekanan Darah dan Mual dengan Diagnosis Risiko Ketidakstabilan Tekanan Darah sebagai prioritas pertama dan diikuti dengan Diagnosis Mual.

Penelitian ini juga menemukan bahwa aspek pengkajian mengenai kecemasan terkait hospitalisasi, kondisi lingkungan sosial dan tempat tinggal, mekanisme koping, keyakinan terkait hospitalisasi, penerimaan diri, dan hobi tidak didukung oleh sistem informasi keperawatan yang digunakan pada lokasi penelitian karena bersifat check-list dan isian singkat. Aktivitas sehari-hari yang dapat didokumentasikan terkait aktivitas sebelum dan sesudah sakit untuk membandingkan aktivitas yang masih dan sudah tidak dapat dilakukan lagi oleh pasien. Sedangkan contact person yang didokumentasikan adalah penanggung jawab pasien yang biasanya merupakan anggota keluarga pasien. Hal ini yang dikeluhkan oleh perawat sehingga mengakibatkan dokumentasi keperawatan tidak mencantumkan data yang spesifik. 
Diagnosis yang telah ditegakkan perlu dibuat target luaran guna menyelesaikan masalah keperawatan dengan mengatasi penyebab atau tanda gejalanya, sehingga tujuan yang dibuat harus berdasarkan diagnosis. Tujuan yang telah dibuat tersebut kemudian dianalisis untuk pembuatan rencana intervensi yang diperlukan untuk mencapai tujuan. Sistematika analisis pada proses tersebut menunjukkan pentingnya dan krusialnya diagnosis yang ditegakkan oleh perawat atau sebagai produk/hasil analisis perawat terhadap proses kajian berdasarkan tanda gejala yang dirasakan atau muncul pada pasien. Peran kritis diagnosis akan berdampak pada penetapan tujuan dan perencanaan intervensi yang berorientasi pada penyelesaian masalah keperawatan.

\section{Penutup}

Simpulan pada penelitian ini menunjukkan bahwa sebagian besar dokumen memiliki kualitas sedang pada dimensi diagnosis sebagai proses, sebagian dokumen memiliki kualitas sedang pada dimensi diagnosis sebagai produk, sebagian besar dokumen memiliki kualitas sedang pada dimensi intervensi, dan sebagian besar dokumen memiliki kualitas sedang pada dimensi luaran keperawatan.Diagnosis keperawatan yang sama ditegakkan oleh perawat ruangan dan peneliti adalah Bersihan jalan napas tidak efektif dan pola napas tidak efektif.Diagnosis keperawatan yang ditegakkan oleh peneliti tidak hanya meliputi aspek fisik, namun juga psikososial.

\section{Daftar Pustaka}

1. Apriyani, H. (2015). IDENTIFIKASI DIAGNOSIS KEPERAWATAN PADA PASIEN DI RUANG PARU SEBUAH RUMAH SAKIT. Jurnal Keperawatan, 11(1).

2. Astarani, K., \& Pradinata, M. J. (2015) Pentingnya Perilaku Empati Perawat dalam Melaksanakan Asuhan Keperawatan JURNAL STIKES RS Baptis Kediri, 8(1)

3. Atmanto, A.P., Aggorowati, \& Muhammad, R. (2020). EFEKTIFITAS PEDOMAN PENDOKUMENTASIAN DIAGNOSA DAN INTERVENSI KEPERAWATAN BERBASIS ANDROID TERHADAP PENINGKATAN MUTU DOKUMENTASI KEPERAWATAN DI RUANG RAWAT INAP. Jurnal Keperawatan dan Kesehatan Masyarakat STIKES Cendekia Utama Kudus, 9(1).

4. Efendy, M. A. A., \& Purwandari, R. (2012). Perbedaan tingkat kualitas dokumentasi proses keperawatan sebelum dan sesudah penerapan NANDA-I, NIC, dan NOC. Jurnal Keperawatan Soedirman, 7(2), 67-77.

5. Koerniawan, D., Novita, E. D., \& Srimiyati. (2020). APLIKASI STANDAR PROSES KEPERAWATAN: DIAGNOSIS, OUTCOME, DAN INTERVENSI PADA ASUHAN KEPERAWATAN. Jurnal Keperawatan Silampari, 3(2), 739-751.

6. Miming Oxyandi, S. (2018). ANALISIS KINERJA PERAWAT (2015). Pentingnya Empati Melaksanakan Perawat PELAKSANA PEMBERIASN KEPERAWATAN DALAM ASUHAN DI INSTALASI RAWAT INAP. Jurnal'Aisyiyah Medika, 2(1).

7. Rachmania, D., Nursalam., Yunitasari, E. (2016). Pengembangan instrumen diagnosis \& intervensi keperawatan berbasis standardized nursing language (NANDA, NOC, NIC). Jurnal Ners Vol 11 (2), 157-163.

8. Ramdani, H.T., \& Sulastini. (2019). EFEKTIVITAS NURSING DIAGNOSTIC MOBILE 
TERHADAP PENDOKUMENTASIAN DIAGNOSA KEPERAWATAN PADA MAHASISWA YANG MELAKSANAKAN PRAKTIK BELAJAR LAPANGAN. Jurnal Keperawatan Dirgahayu, $1(2)$.

9. Simamora, R. H., Bukit, E., Purba, J. M., \& Siahaan, J. (2017). Penguatan kinerja perawat dalam pemberian asuhan keperawatan melalui pelatihan ronde keperawatan di rumah sakit royal prima medan. Jurnal pengabdian kepada masyarakat, 23(2), 300-304.

10. Simamora, R. H. (2019). Socialization of Information Technology Utilization and Knowledge of Information System Effectiveness at Hospital Nurses in Medan, North Sumatra. Editorial Preface From the Desk of Managing Editor...,10(9).

11. Supratti, \& Ashriady. (2016). PENDOKUMENTASIAN STANDAR ASUHAN KEPERAWATAN DI RUMAH SAKIT UMUM DAERAH MAMUJU, INDONESIA. Jurnal Kesehatan MANARANG, 2(1).

12. Wirdah, H., \& Yusuf, M. (2016). Penerapan Asuhan Keperawatan Oleh Perawat Pelaksana di Rumah Sakit Banda Aceh. Jurnal Ilmiah Mahasiswa Fakultas Keperawatan, 1(1). 